\title{
Taxonomic value of the petiole anatomy in the genus Cinnamomum (Lauraceae) found in Sri Lanka
}

\author{
Pushpa Damayanthi Abeysinghe ${ }^{1 *}$ and Tanya Scharaschkin ${ }^{2}$ \\ ${ }^{1}$ Department of Botany, Faculty of Science, University of Ruhuna, Matara, Sri Lanka \\ ${ }^{2}$ Queensland University of Technology, Brisbane, Australia \\ *Correspondence: pushpa@bot.ruh.ac.lk; iD https://orcid.org/0000-0002-2026-3014 \\ Received: $9^{\text {th }}$ November 2018, Revised: $28^{\text {th }}$ January 2019, Accepted: $20^{\text {th }}$ February 2019
}

\begin{abstract}
We assessed the petiole anatomy of 8 species of Sri Lankan Cinnamomum (C. capparu-coronde, C. citriodorum, C. dubium, C. litseaefolium, C. ovalifolium, C. rivulorum and C. sinharajaense and $C$. verum) belonging to the family Lauraceae using light microscopy in the petiole anatomy for identification and classification of species. This is the first report on comprehensive petiole anatomy in Cinnamomum species. The distinctive, important and key taxonomic characteristics of the petiole include the shape and outline of the petiole, the presence of winged extensions, surface grooves on upper surface, presence or absence of trichomes, structure of vascular bundle and stone cell characters (shape, structure, pits and fissure size). These identified petiole characters provide the additional information for the identification of Cinnamomum species. Almost all the characters studied had little difference within a species but vary among the species. However, shape of epidermal cells was relatively constant for all species. All polymorphic characters were used for Principal Component Analysis (PCA) and species were divided into three main clusters. The PCA revealed that acicular crystals, cluster of crystals, trichomes and trichome abundance contribute to the first component that account for $31.76 \%$ total variance. Shape of the petiole, upper surface wings and raphides are the major loading characters to the second component. Therefore, anatomical structures of the petiole are useful in the identification and may help for crop improvement, conservation, management and future usefulness of germplasm resources of Cinnamomum species.
\end{abstract}

Keywords. Cinnamomum, Lauraceae, PCA, petiole anatomy, taxonomy

\section{Introduction}

Lauraceae is a large family represented by about 50 genera and approximately 2,500 to 3,000 species in the world (Nishida and van der Werff 2007). In Sri 
Lanka, the family is represented by 41 species in 9 genera (Senaratna 2001) The genus Cinnamomum includes eight species (C. capparu-coronde Blume, C. citriodorum Thw., C. dubium Nees, C. litseaefolium Thw., C. ovalifolium Wight, C. rivulorum Kosterm, C. sinharajaense Kosterm and C. verum Presl) (Sritharan 1984). Many species of Lauraceae in the world are used for medicinal and food purposes (Khan et al. 2003, Faixov and Faix 2008, Smerq and Sharma 2011, Pugazhenthi and Suganthi 2013, Wang et al. 2013, Nwokwa et al. 2014). These include bay (Laurus nobilis) leaves for flavoring foods and medicinal purposes (Pugazhenthi and Suganthi (2013), camphor (Cinnamomum camphora) for moth repellant and medicinal purposes (Nwokwa et al. 2014), C. verum for food flavouring (Wang et al. 2013), myrtlewood (Umbellularia californica) and white stinkwood (Celtis africana) for furniture, sassafras (Sassafras albidum) for tea (Jackson 2005) and avocado as edible fruits (Persea americana). Cinnamomum verum is one of the most economically important spices in Sri Lanka which produces about $70 \%$ of the world bark production of cinnamon (Anon. 2006). C. capparucoronde, C. citriodorum, C. dubium, C. ovalifolium and C. sinharajaense are considered as vulnerable species while C. litseaefolium and $C$. rivulorum are endangered (MOE 2012). The morphology of Cinnamomum species found in Sri Lanka has been studied and they show high variation in gross morphology of leaves among species and also within species, which precludes diagnosis and species identification (Sritharan 1984). Flowers are rare and flowering times of the different species are dissimilar. Therefore, identification of Cinnamomum species is difficult using only vegetative and floral morphological characters. Anatomical features are widely used in plant taxonomy in families. For instance, for infra-generic classification of Fabaceae (Michael and Soladoye 1982), Rubiaceae (Martínez-Cabrera et al. 2009), Anacardiaceae (Mangifera indica L.), Cruciferae (Brassicaceae), (Gorovoy et al. 2011), Lamiaceae (Akçin et al. 2011) and Rutaceae (Vun et al. 2015), to delineate the taxa even at the species level for Momordica, Cucurbitaceae (Aguoru and Okoli 2012) and Mangifera indica varieties (Sharma et al. 2012) especially when the floral parts or fruits are not available (Ayomipo et al. 2015), identification and authentification of medicinal plants (Ingole and Kaikade, 2015). Moreover, the anatomical characteristics of the petiole have been used to describe the fossil genus Heleophyton (Matias et al. 2007). Although the classification of plants is mainly based on morphological and anatomical concepts, there is no comprehensive information regarding the anatomy of Cinnamomum species found in Sri Lanka and anatomical descriptions of Cinnamomum species are scarce. Therefore, the study described the petiole anatomy of eight Cinnamomum species using light microscopy (LM) and discussed the possibility of utilizing these features among the investigated species. 


\section{Materials and methods}

The first fully expanded three to five new leaf samples from three individuals of 8 species of Cinnamomum were collected from sun-exposed branches from healthy individuals of more or less similar age from the Cinnamon Research Station, Department of Export Agriculture, Palolpitiya, Matara, Sri Lanka and preserved in FAA (Huang and Yeung, 2015). After preserving them for one week, samples were transferred to $70 \%$ alcohol and the fixed samples were rehydrated in graded series (Retamales et al. 2015). Hand sections of median portion of the petioles from preserved sampled were taken using a sharp blade. Three or five petiole samples per each species were observed under Nikon eclipse 50i compound microscope and images captured using the Nikon NIS-Elements imaging software (Nikon Instruments, Amsterdam, The Netherlands). Polymorphic characters were observed using the taken images and recorded (Table 1). All petiole anatomical features presented in Table 1 were coded for cluster analysis. A data matrix (Table 2) was generated for the calculation of the similarity among the species using the data present in Table 1. Cluster analysis of the species was carried out using Minitab 17 software package using the Euclidean distance treating with the complete method and unweighted pair-group method with arithmetic averages (UPGMA) as the sorting strategy. In this study, principal components analysis (PCA) was used to analyze the 18 variables to reduce the dimension of factors.

\section{Results and discussion}

Anatomical evidence has been exploited in delimiting taxa: Asteraceae (Mabel et al. 2013), Salvia species (Özdemir et al. 2016) and Nepeta species of Lamiaceae (Shahri et al. 2016) and petiole anatomy is one of the important biomarkers (Ingole and Kaikade, 2015). However, no data were available for petiole anatomy of Sri Lankan Cinnamomum species. Furthermore, no recent literature is available on the taxonomic revision of Cinnamomum species found in Sri Lanka except Abeywikrama (1973). In Australia, a revision of family Lauraceae has been conducted using only morphological characters (Hyland 1986). Our comprehensive study of petiole anatomy of the Cinnamomum species showed marked variations which were of systematic and taxonomic significance. Polymorphic anatomical features studied are summarized in Table 1. Character number is preceded by \# and states of the same character are assigned serial numbers in the parenthesis. On the basis of studied characters, wing extension, shape and outline of the petiole in a cross section, trichomes (presence, abundance and number of cells), grooved margins in upper surface, vascular bundle (shape, structure, and arrangement), pits and pore size of the stone cells were unique to some species (Figures 1 and 2). The results will be presented in 
three parts, (1) Survey of the petiole anatomical and micromorphological characters, (2) Cluster analysis, and (3) an identification key of studied species using polymorphic anatomical and micromorphological characters.

\subsection{Survey of the petiole anatomical and micromorphological characters}

\section{Petiole shape}

The research on petiole structure of Cinnamomum species has allowed us to reveal species differences. Petiole shapes showed distinct differences among the examined samples. All the petioles were bifacial, each petiole has its own structral properties. The petiole has seven different shapes of the entire petiole outline (circular/sub-circular to somewhat reniform) in cross section and they can be catergorized as Type I, II, III, IV, V, VI and VII (Table 1). Each petiole has its own structral properties. Petioles with a shallow adaxial groove/s can be seen on all the petioles except $C$. citriodorum (somewhat flat) while $C$. litseaefolium, $C$. rivulorum and $C$. sinharajaense have highly concave upper surface while in $C$. capparu-corindo and $C$. verum has slight concave shape. Apart from the adaxial groove, secondary ridges accompanying shallow grooves may be observed in sections but these were not constant between specimens of the same species. Petiole shapes show distinct differences among the examined types. However, C. citriodorum and C. ovalifolium have mostly similar round shape. C. dubium and $C$. litseaefolium have more or less oval and nonsymmetrical shape (along the vertical axis) while C. cappru-corindo, C. citriodorum C. ovalifolium, $C$. sinharajaense and $C$. verum have symmetrical shape. C. cappru-corindo, $C$. citriodorum and $C$. ovalifolium have more or less flat adaxial surface. $C$. capparu-corindo shows the winged extensions of the adaxial side. C. litseaefolium, $C$. rivulorum and $C$. sinharajaense have highly concave upper surface and in $C$. verum has slight concave upper surface. The upper surface of C. capparu-corindo and Ocotea duckei, a member of family Lauraceae has a very much similar structure with winged extensions (Coutinho et al. 2006). Similar dorsiventral structure has been observed in Cinnamomum pauciflorum leaf anatomy (Baruah and Nath, 2006). However, the petiole anatomy of Cinnamomum species is scanty.

\section{Cuticle and upper surface}

The adaxial and abaxial epidermis are covered with undulate thick film of epicuticular waxes. The cuticle may be smooth or undulated (Figure 1a and 1b), cuticular striations occur frequently (C. dubium, C. litseaefolium, $C$. rivulorum, C. sinharajaense and C. verum), or both can be found in all species. 
Table 1: Comparison of the polymorphic qualitative characters of petiole of the studied Cinnamomum species. Character number is preceded by \# and states of the same character are assigned serial numbers within parenthesis.

\begin{tabular}{|c|c|c|c|c|c|c|c|c|c|}
\hline $\bar{\Xi}$ & Type & Type I & Type II & Type III & Type IV & Type II & Type V & Type VI & Type VII \\
\hline 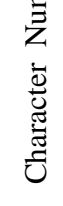 & $\begin{array}{l}\text { Shape and } \\
\text { species } \\
\text { Character } \\
\text { (code) }\end{array}$ & $\begin{array}{l}\text { (2) } \\
\text { C. capparu- } \\
\text { corondo }\end{array}$ & $\begin{array}{l}\text { C. } \\
\text { citriodorum }\end{array}$ & C. dubium - & C. litseaefolium & C. ovalifolium & $\begin{array}{l}\text { edity } \\
\text { с. rivulorum }\end{array}$ & $\begin{array}{l}\text { (n) } \\
\text { C. } \\
\text { sinharajaense }\end{array}$ & $\begin{array}{l}\text { C. verum } \\
\text { Cond }\end{array}$ \\
\hline \#1 & Symmetry (SY) & $\begin{array}{l}\text { Symmetrical } \\
\text { (1) }\end{array}$ & $\begin{array}{l}\text { Symmetrical } \\
\text { (1) }\end{array}$ & $\begin{array}{l}\text { Not } \\
\text { symmetrical (2) }\end{array}$ & $\begin{array}{l}\text { Not symmetrical } \\
\text { (2) }\end{array}$ & $\begin{array}{l}\text { Symmetrical } \\
\text { (1) }\end{array}$ & $\begin{array}{l}\text { Symmetrical } \\
\text { (1) }\end{array}$ & $\begin{array}{l}\text { Symmetrical } \\
\text { (1) }\end{array}$ & $\begin{array}{l}\text { Symmetrical } \\
\text { (1) }\end{array}$ \\
\hline \#2 & $\begin{array}{l}\text { Shape of the } \\
\text { entire petiole in } \\
\text { cross section } \\
\text { (SH) }\end{array}$ & Round (1) & Round (1) & Oval shaped (2) & Reniform (3) & Round (1) & Roundish (4) & Roundish (4) & Roundish (4) \\
\hline \#3 & $\begin{array}{l}\text { Upper surface } \\
\text { wings (USW) }\end{array}$ & Present (1) & Absent (2) & Absent (2) & Absent (2) & Absent (2) & Absent (2) & Absent (2) & Absent (2) \\
\hline$\# 4$ & $\begin{array}{l}\text { Upper surface } \\
\text { groove (USG) }\end{array}$ & Slight (2) & No groove (1) & Undulate (3) & $\begin{array}{l}\text { Broad grove } \\
\text { (5) }\end{array}$ & Slight (2) & deep grove (5) & Medium (4) & Medium (4) \\
\hline \#5 & Trichomes (T) & Absent (2) & Absent (2) & Present (1) & Absent (2) & Present (1) & Present (1) & Absent (2) & Absent (2) \\
\hline \#6 & $\begin{array}{l}\text { Trichome } \\
\text { abundance } \\
\text { (TA) }\end{array}$ & Absent (2) & Absent (2) & High (3) & Absent (2) & Low (1) & High (3) & Absent (2) & Absent (2) \\
\hline \#7 & $\begin{array}{l}\text { Trichome no. } \\
\text { of cells (NT) }\end{array}$ & Absent (2) & Absent (2) & $\begin{array}{l}\text { Unicellular } \\
\text { (1) }\end{array}$ & Absent (2) & $\begin{array}{l}\text { Unicellular } \\
\text { and bicellular } \\
\text { (3) }\end{array}$ & $\begin{array}{l}\text { Unicellular } \\
\text { and bicellular } \\
\text { (3) }\end{array}$ & Absent (2) & Absent (2) \\
\hline$\# 8$ & $\begin{array}{l}\text { Shape of the } \\
\text { trichomes (ST) }\end{array}$ & Absent (2) & Absent (2) & $\begin{array}{l}\text { Straight or bent } \\
\text { (1) }\end{array}$ & Absent (2) & Straight (3) & Straight (3) & Absent (2) & Absent (2) \\
\hline
\end{tabular}




\begin{tabular}{|c|c|c|c|c|c|c|c|c|c|}
\hline & Type & Type I & Type II & Type III & Type IV & Type II & Type V & Type VI & Type VII \\
\hline$\# 9$ & $\begin{array}{l}\text { Vascular } \\
\text { bundle (VB) }\end{array}$ & $\begin{array}{l}\text { Partially } \\
\text { dissected into } \\
\text { 3-segments (3) }\end{array}$ & $\begin{array}{l}\text { Simple } \\
\text { open arc } \\
(1)\end{array}$ & $\begin{array}{l}\text { Clearly } \\
\text { separated } \\
\text { into three (4) }\end{array}$ & $\begin{array}{l}\text { Partially } \\
\text { dissected into 3- } \\
\text { segments (3) }\end{array}$ & $\begin{array}{l}\text { Simple open } \\
\operatorname{arc~(1)~}\end{array}$ & $\begin{array}{l}\text { Simple } \\
\text { open arc } \\
(1)\end{array}$ & $\begin{array}{l}\text { Simple open } \\
\text { arc with } \\
\text { slightly curved } \\
\text { ends (2) }\end{array}$ & $\begin{array}{l}\text { Simple open } \\
\text { arc with } \\
\text { slightly curved } \\
\text { ends (2) }\end{array}$ \\
\hline \#10 & $\begin{array}{l}\text { No. of } \\
\text { collateral } \\
\text { vessels (CV) }\end{array}$ & $\begin{array}{l}\sim 20-25 \\
\text { collateral } \\
\text { vessels (2) }\end{array}$ & $\begin{array}{l}\sim 17-20 \\
\text { collateral } \\
\text { vessels (1) }\end{array}$ & $\begin{array}{l}\sim 25-30 \\
\text { collateral } \\
\text { vessels (3) }\end{array}$ & $\begin{array}{l}\sim 25-30 \\
\text { collateral vessels } \\
\text { (3) }\end{array}$ & $\begin{array}{l}\sim 25-30 \\
\text { collateral } \\
\text { vessels (3) }\end{array}$ & $\begin{array}{l}\sim 20-25 \\
\text { collateral } \\
\text { vessels (2) }\end{array}$ & $\begin{array}{l}\sim 40-45 \\
\text { collateral } \\
\text { vessels (4) }\end{array}$ & $\begin{array}{l}\sim 20-25 \\
\text { collateral } \\
\text { vessels (2) }\end{array}$ \\
\hline \#11 & $\begin{array}{l}\text { Sand crystals } \\
\text { (SC) }\end{array}$ & Present (1) & Absent (2) & Present (1) & Absent (2) & Absent (2) & Present (1) & Absent (2) & Absent (2) \\
\hline$\# 12$ & $\begin{array}{l}\text { Elongated } \\
\text { shaped crystal } \\
\text { (ESC) }\end{array}$ & Present (1) & Present (1) & Present (1) & Present (1) & Present (1) & Present (1) & Absent (2) & Present (1) \\
\hline \#13 & $\begin{array}{l}\text { Acicular } \\
\text { shaped } \\
\text { crystals (AC) }\end{array}$ & Present (1) & Absent (2) & Present (1) & Absent (2) & Present (1) & Present (1) & Present (1) & Present (1) \\
\hline$\# 14$ & $\begin{array}{l}\text { Rectangular } \\
\text { shaped (RS) }\end{array}$ & Present (1) & Absent (2) & Present (1) & Present (1) & Present (1) & Absent (2) & Absent (2) & Absent (2) \\
\hline \#15 & $\begin{array}{l}\text { Box-shaped } \\
\text { (BL) }\end{array}$ & Present (1) & Absent (2) & Present (1) & Present (1) & Absent (2) & Present (1) & Present (1) & Absent (2) \\
\hline \#16 & $\begin{array}{l}\text { Shape of the } \\
\text { stone cells - } \\
\text { sclerides (SS) }\end{array}$ & Elongated (1) & Elongated (1) & $\begin{array}{l}\text { Isodiametric } \\
(2)\end{array}$ & Isodiametric (2) & $\begin{array}{l}\text { Isodiametric } \\
(2)\end{array}$ & $\begin{array}{l}\text { Isodiametric } \\
\text { (2) }\end{array}$ & Elongated (1) & $\begin{array}{l}\text { Isodiametric } \\
\text { (2) }\end{array}$ \\
\hline$\# 17$ & $\begin{array}{l}\text { Porosity of } \\
\text { the stone } \\
\text { cells (PC) }\end{array}$ & $\begin{array}{l}\text { Finely porous } \\
\text { (1) }\end{array}$ & $\begin{array}{l}\text { Strongly } \\
\text { porous (2) }\end{array}$ & $\begin{array}{l}\text { Finely porous } \\
\text { (1) }\end{array}$ & $\begin{array}{l}\text { Strongly porous } \\
\text { (2) }\end{array}$ & Small pore (3) & Small pore (3) & $\begin{array}{l}\text { Finely porous } \\
\text { (1) }\end{array}$ & Small pore (3) \\
\hline \#18 & $\begin{array}{l}\text { Pits of stone } \\
\text { cells (PS) }\end{array}$ & Remarkable (3) & $\begin{array}{l}\text { Not } \\
\text { observable (2) }\end{array}$ & observable (1) & $\begin{array}{l}\text { Not observable } \\
\text { (2) }\end{array}$ & Remarkable (3) & $\begin{array}{l}\text { Observable } \\
\text { (1) }\end{array}$ & Observable (1) & Observable (1) \\
\hline
\end{tabular}


Cuticle and epidermal cells were observed to be mostly similar in all materials studied. İn O. duckei, thick and smooth cuticle have been observed by Coutinho et al. (2006). In this study, Cinnamomum species were collected from the fully sun exposed plants. Therefore, thick cuticle helps to prevent the water loss efficiently, as well as the leaf from wilting when the cells dehydrate (Metcalfe and Chalk, 1972). Simple, unicellular/bicellular, falcate (C. dubium, Figure 1c) unicellular/multicellular (C. rivulorum 1d) trichomes are present only on adaxial surface (Figures 1). All trichomes are non glandular and are absent in other species. As we observed similar results have been obtained for leaf epidermis and thick-walled erect hair on the abaxial surface of the leaf of Cinnamomum species by Bakker et al. (1992). Kamel and Loutfy (2001) have identified the unbranched trichomes of some members of the family Lauraceae.
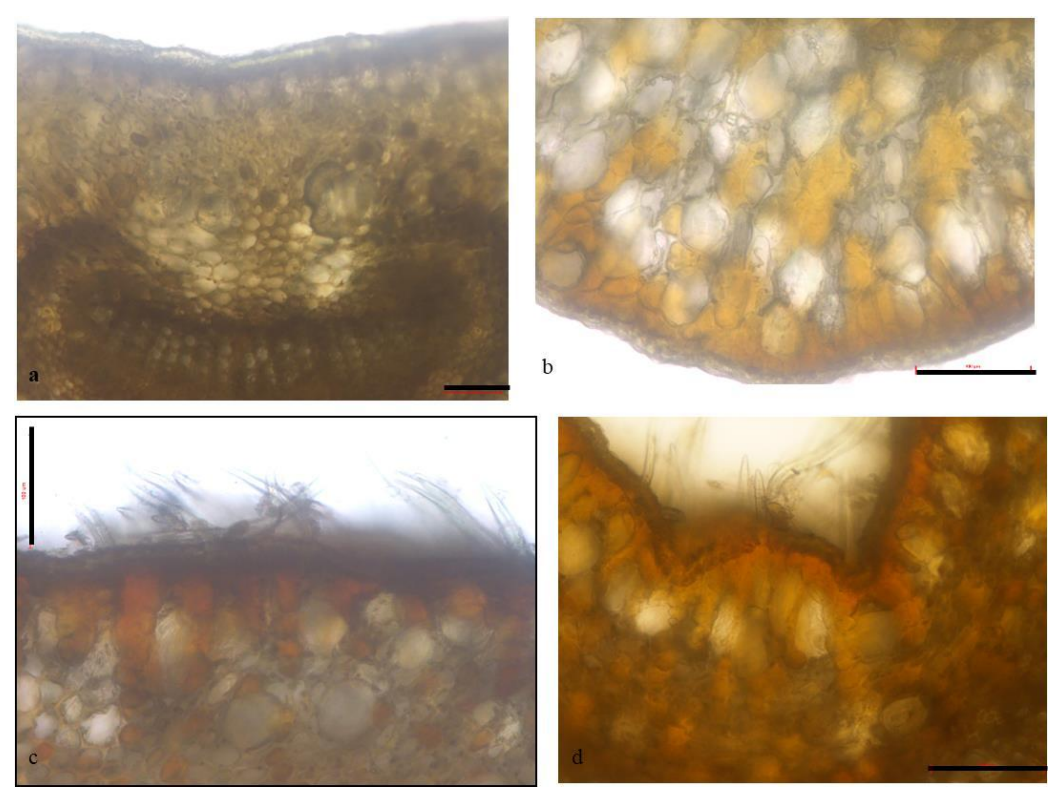

Fig 1. Cuticle structure, a) upper surface of Cinnamomum citriodorum b) lower surface of C. rivulorum c) bicellular/non glandular trichomes of C. dubium d) C. rivulorum with unicellular/multicellular trichomes. Scale bar is $100 \mathrm{~nm}$.

\section{Vascular tissues}

The vascular system has received the most attention in the study of petiole anatomy (Kocsis and Borhidi 2003, Noraini et al. 2016, Talip et al. 2017, Long and Oskolski 2018). According to the pattern of vascular tissue arrangement, the petiole is classified into eight types and is shown in Figures 2a- 2h. Different shape of vascular bundle of Cinnamomum species have 
allowed us to reveal species differences. The shape of the vascular tissues in all the species studied has only an open arc with no lateral bundles. Figure 2 shows the petioles with vascular bundles based on shape and bundle arrangements in the petioles of each species. C. cappru-corindo, C. sinharajaense and $C$. verum which has an open arc with slightly curve ends towards the centre (incurving), thereby presenting a wide arc-shaped appearance. In $C$. dubium, the shape of the vascular bundle is quite characteristic; the open arc has clearly separated into three segments (multilobed, Figures 2c) while in C. capparu-corindo and C. litseaefolium, open arc has partially dissected into 3 segments (Figures 3a, 3d). C. citriodorum (Figures $3 \mathrm{~b}$ ) and $C$. rivulorum (Figures $3 \mathrm{f}$ ) has more or less similar structure; ' $C$ ' shaped open arc and a large number of collateral vessels are arranged vertically. C. verum has slightly curved ends (Figures 3 h).

Vascular bundle is open and consists of more than ten collateral vesseles. The number of collateral vessels differs among the species; C. capparucorindo ( \pm 24$),$ C. citriodorum ( \pm 17$), C$. dubium ( \pm 29$)$, C. litseaefolium ( \pm 28$)$, C. ovalifolium ( \pm 29$), C$. rivulorum ( \pm 22$), C$. sinharajaense $( \pm 42)$, and $C$. Verum ( \pm 27 ). Different patterns of vascular bundle of Cinnamomum species have allowed to reveal species differences. Kamel and Loutfy (2001) have observed the crescent shape vascular strands in some members of Lauraceae. The vascular bundle is enclosed by parenchyma cells with distinctive darkstaining secondary compounds (tannin and phenolic compounds) in all studied species but the color and the density of the deposits vary depending on the species (Figure 2). We also observed the pigmented cells in all the species in ground tissues (Figures $2 \mathrm{a}-2 \mathrm{~h}$ ) which has been observed in worldwide genera of the family Lauraceae (Kamel and Loutfy, 2001).
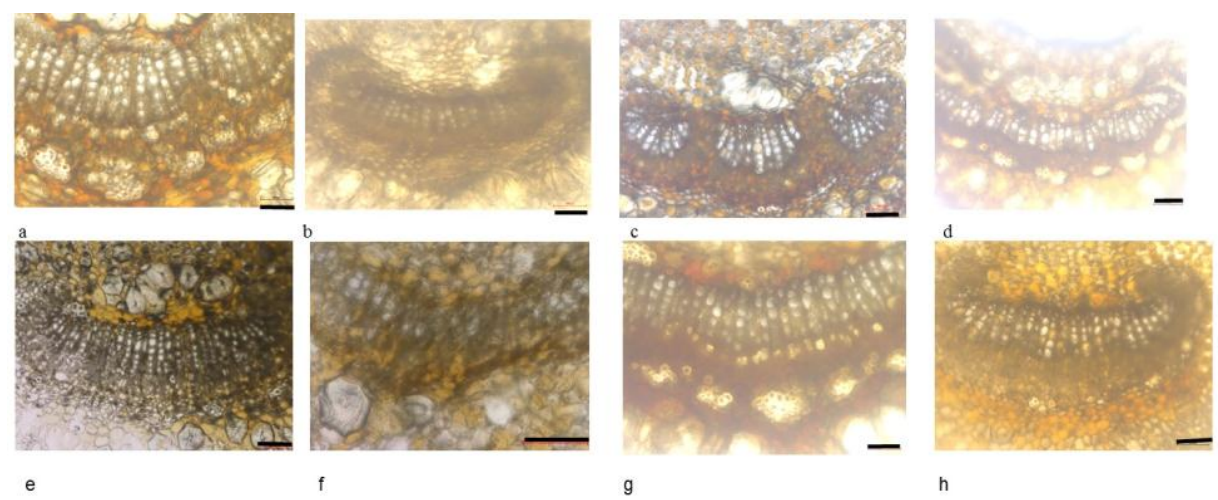

Fig. 2 Different patterns of vascular bundle a) partially dissected into 3 segments of Cinnamomum cappru-corindo, b) simple open arc of C. citriodorum, c) clearly separated into three of $C$. dubium, d) partially dissected into 3 of C. litseaefolium, e and f) simple open arc of $C$. ovalifolium and $C$. rivulorum, $g$ and h) simple open arc with slightly curved ends of $C$. sinharajaense and $C$. verum. 
Therefore, the research on petiole anatomical structure has allowed us to reveal species differences. A similar tissue arrangement; cortex with fundamental parenchyma cells, discontinuous layers of sclerenchymatic cells surround the vascular bundle, open arch vascular bundle, collateral type xylem tissues have been observed in O. duckei (Coutinho et al. 2006). Supporting tissues such as fibers and sclerotic cells are present in the petioles. Tissues of support in the form of a cluster of sclenchymatous cells are observed mainly around the vascular tissues (Figure 2a, b, c). The pattern of the vascular tissues in all the species studied has only an open arc with no lateral bundles (Figure 2a-h), with a discontinuous sclerenchymatous sheath with dark-colored deposits including the cell lumina (Figure 2). Different kinds of vascular patterns are present in the speceis studied (Table 1 and Figures 2a-h). The presence or absence of perivascular tissues appears to be not consistant in all species (Figure 2).

Table 2: Data matrix generated for the calculation of the similarity index among the Cinnamomum species.

\begin{tabular}{|c|c|c|c|c|c|c|c|c|c|c|c|c|c|c|c|c|c|c|}
\hline Species & 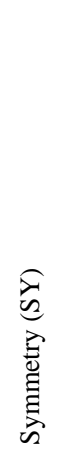 & $\begin{array}{l}\text { 跑 } \\
\text { 岕 } \\
\text { 㫕 }\end{array}$ & 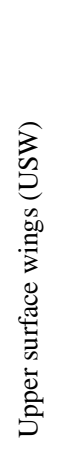 & 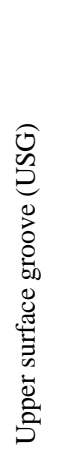 & 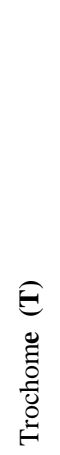 & 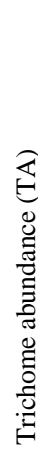 & 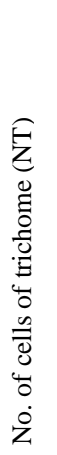 & 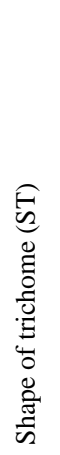 & 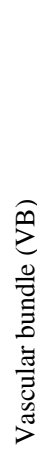 & 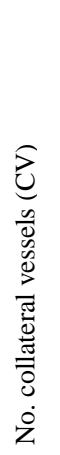 & 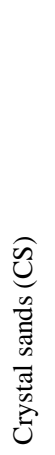 & 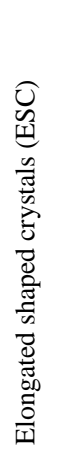 & 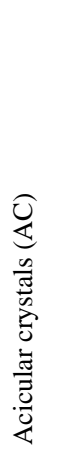 & 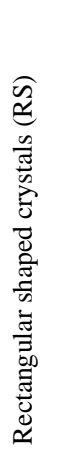 & 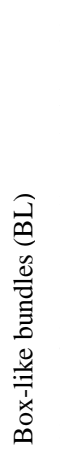 & 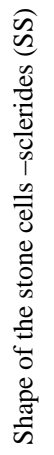 & 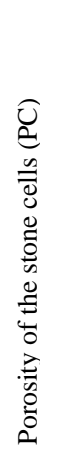 & 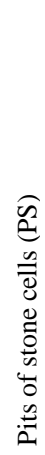 \\
\hline C. cappru-corindo & 1 & 1 & 1 & 2 & 2 & 2 & 2 & 2 & 3 & 2 & 1 & 1 & 1 & 1 & 1 & 1 & 1 & 3 \\
\hline C. citriodorum & 1 & 1 & 2 & 1 & 2 & 2 & 2 & 2 & 1 & 1 & 2 & 1 & 2 & 2 & 2 & 1 & 2 & 2 \\
\hline C. dubium & 2 & 2 & 2 & 3 & 1 & 3 & 1 & 1 & 4 & 3 & 1 & 1 & 1 & 1 & 1 & 2 & 1 & 1 \\
\hline C. litseaefolium & 2 & 3 & 2 & 5 & 2 & 2 & 2 & 2 & 3 & 3 & 2 & 1 & 2 & 1 & 1 & 2 & 2 & 2 \\
\hline C. ovalifolium & 1 & 1 & 2 & 2 & 1 & 1 & 3 & 3 & 1 & 3 & 2 & 1 & 1 & 1 & 2 & 2 & 3 & 3 \\
\hline C. rivulorum & 1 & 4 & 2 & 5 & 1 & 3 & 3 & 1 & 1 & 2 & 1 & 1 & 1 & 2 & 1 & 2 & 3 & 1 \\
\hline C. sinharajaense & 1 & 4 & 2 & 4 & 2 & 2 & 2 & 2 & 2 & 4 & 2 & 2 & 1 & 2 & 1 & 1 & 1 & 1 \\
\hline C. verum & 1 & 4 & 2 & 4 & 2 & 2 & 2 & 2 & 2 & 2 & 2 & 1 & 1 & 2 & 22 & 2 & 3 & 1 \\
\hline
\end{tabular}




\section{Stone cells (sclereids)}

In the cortex, all the species frequently contain different shapes and different sizes of stone cells (sclereids) which lie mainly around the vascular bundle. Although branched stone cells were absent in all studied Cinnamomum species, stone cells have different types depending on the wall structure (whether pitted, non-pitted or rarely pitted, thickness of the wall, size of cell cavity, presence or absence of color deposits in cell contents, etc.). In $C$. capparu-coronde, brachysclereids were greatly elongated, rectangular shaped, the walls were yellowish white and finely porous. The central cavity is narrow and is marked with branched pits (Figure 3a). In C. citriodorum, different sized, elongated shaped light yellowish, irregularly thickened with prominent cavity of the stone cells were observed (Figure 3b). The stone cells of C. dubium, different shapes and sizes of brachyssclerides were yellowish white, less porous and have branched pits. The central cavity is not prominent. In $C$. litseaefolium, different shapes of stone cells were concentrated above the vascular bundle and scattered below the middle part the vascular bundle and beneath the epidermis (Figure 2d), mostly round in form, pores were visible. The diagnostic stone cell of $C$. ovalifolium (Figure $2 \mathrm{e})$, round in outline, the walls were yellowish and the central cavity has pits. In C. rivulorum, brachysclereids have different shapes and sizes (Figure 2f), the pits were prominent, central cavity is observable. The different shapes and sizes stone cells of $C$. sinharajaense were elongated shaped, the walls were pitted, finely porous and contain tannins (Figure 2g).

A very few stone cells of $C$. verum were scattered around the the bundle (Figure 1h), vary in shape from square to nearly round, similar to the stone cells of $C$. ovalifolium, the walls were yellow and very thick, equally thickened, the central cavity is small which is filled with masses of reddishbrown tannin. Therefore, the color of the walls of the different stone cells varies. The width of the cell cavity varies considerably in the stone cells of the studied species. In C. citriodorum and C. litseaefolium the cell cavity is greater than the thickness of the cell wall. The cavity of $C$. cappru-corindo, C. dubium and C. sinharajaense is finely porous. The pits were prominent in C. cappru-corindo, C. dubium, C. ovalifolium and C. sinharajaense. The cavity of many stone cells contains colored deposits such as tannins. The porosity and the pits (presence or absence) of stone cells were the different and diagnostic characters of the Cinnamomum species. Moreover, they were different in abundance; C. capparu-coronde $\sim 50$, C. citriodorum $\sim 30, C$. dubium $\sim 15$, C. litseaefolium $\sim 10$, C. ovalifolium $\sim 25$, C. rivulorum $\sim 8, C$. sinharajaense $\sim 25$ and C. verum $\sim 8$ (Figure 3). 

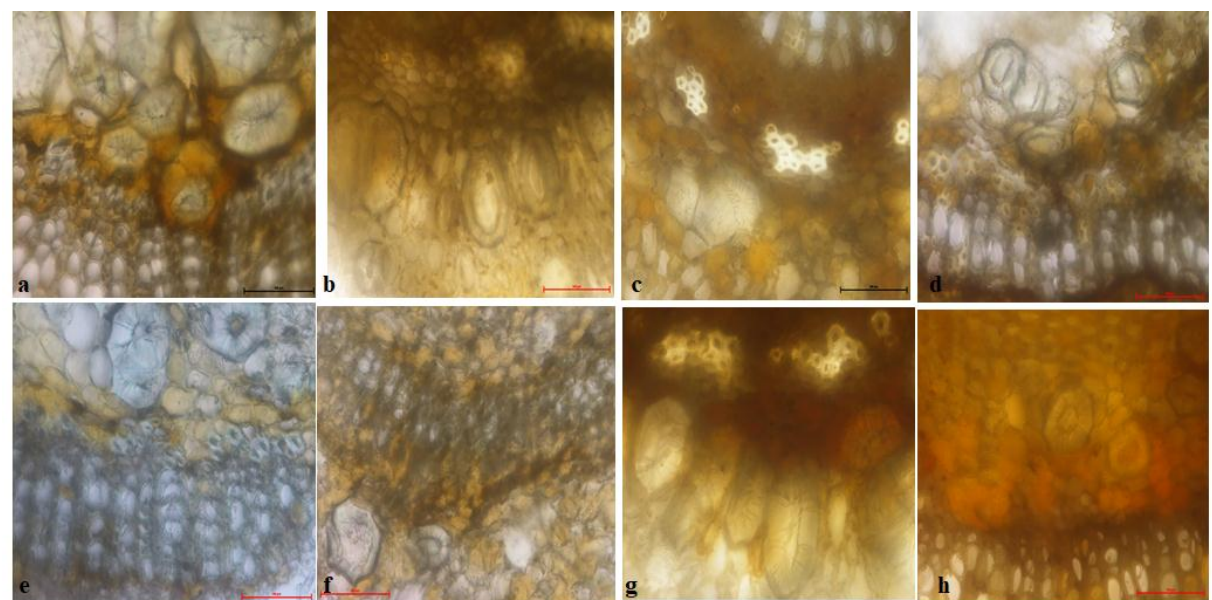

Fig. 3 Different sclereids of studied species. a) brachysclereids, or stone cells of $C$. cappru-corindo, b) macro-sclereids, elongated and columnar (rod-like) cells of $C$. citriodorum, c) brachysclereids, or stone cells of C. dubium, d) brachysclereids with thin cell wall of $C$. litseaefolium, e) brachysclereids of $C$. ovalifolium $\mathrm{f}$ ) brachysclereids, or stone cells of $C$. rivulorum g) macro-sclereids, elongated and columnar (rod-like) cells of $C$. sinharajaense h) brachysclereids, or stone cells of with thin cell wall of $C$. verum $(100 \mu \mathrm{m}$ scale bar).

\section{Crystals and secondary compounds}

Crystals were present in the parenchyma and collenchyma cells in all the species. In general, we found crystals as prism, styloids (elongated shaped), sand crystal, acicular shaped crystals, cluster of crystals, isolated crystals, rectangular shaped and box-shaped of $\mathrm{CaO}_{\mathrm{x}}$ crystals in Cinnamomum species. Crystals found in petioles were divided as groups (agglomeration same shape or different shape crystals) and single crystals. Styloid crystals which were lined up neatly were generally found in groups.

Although the crystals were present, both druses and raphides were absent. The staining reaction of ruthenium red confirmed the presence of pectin in the mesophyll of all the species studied. In petiole, idioblasts are rich in tannins and polyphenols mainly in parenchyma cells contained big vacuoles, xylem and phloem cells. Those compounds were easily observed due to the redbrown color with the ferric chloride staining. The presence of crystals, stone cells and dark - stained deposits to particular Cinnamomum species suggests the potential taxonomic value of these features. 


\subsection{Cluster analysis}

\section{Dendrogram of eight Cinnamomum species based on petiole anatomy}

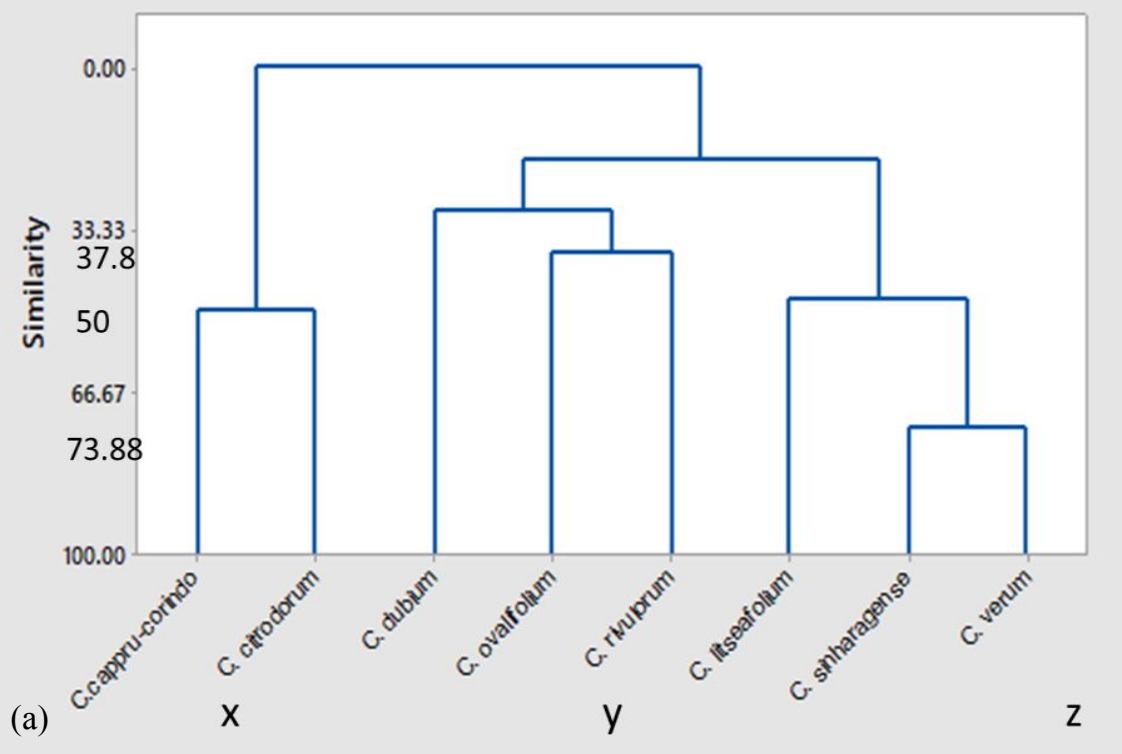

Biplot of Cinnamomum species based on petiole anatomical data

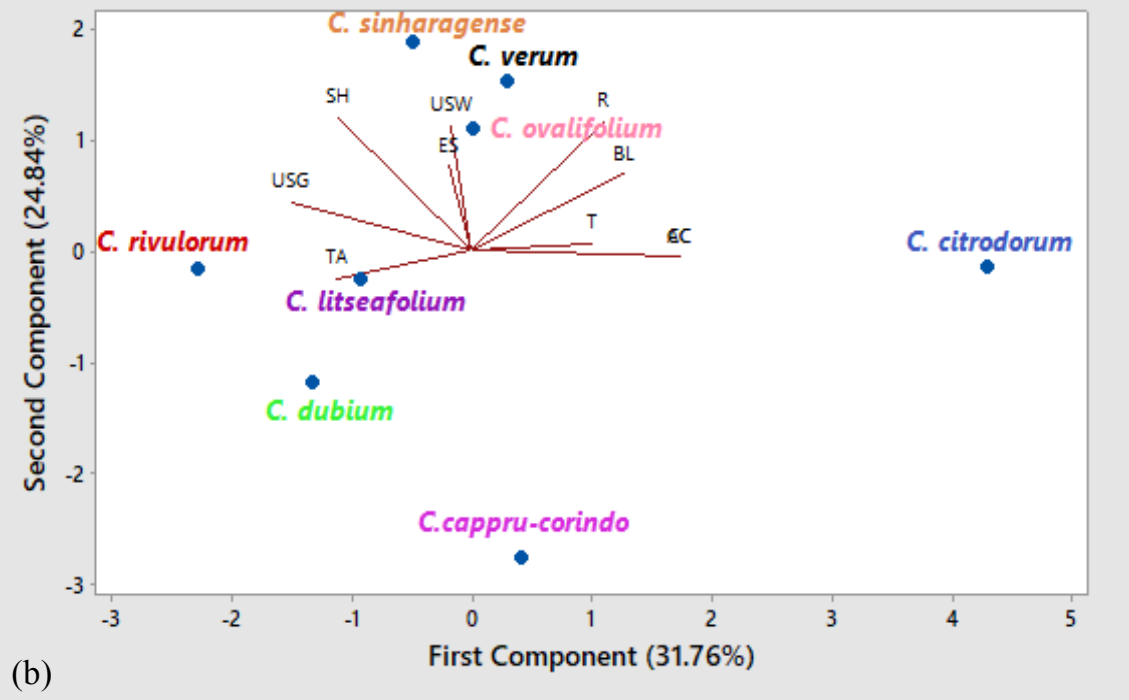

Fig. 4 a) Cluster analysis of Cinnamomum species based on all anatomical characters b) Biplot on the first and second eigenvectors of principal components (PC) of 10 informative characters out of all (18) anatomical characters of Cinnamomum species sampled from Sri Lanka. 
In an attempt to study the relationship of these species, the petiole anatomical characters were analyzed. In order to get some insight in the overall similarities of the individual species of Cinnamomum, cluster analyses were applied. Based on the data matrix (Table 2) prepared using the polymorphic characters, cluster analysis was carried and resulted the three main clusters (Figure 4a); x) C. capparu-corindo and C. citriodorum y) C. dubium, C. ovalifolium, C. rivulorum and z) C. litseaefolium and C. sinharajaense and $C$. verum. Further, $C$. sinharajaense and $C$. verum have clustered very closely and clearly shows the higher similarity between two species. C. sinharajaense and $C$. verum $(\mathrm{z})$ have the highest similarity value, 73.8 for all studied characters and $C$. sinharajaense and $C$. verum have clustered with $C$. litseaefolium at the similarity value $\sim 50$. Moreover, C. capparu-corindo and C. citriodorum have clustered $(\mathrm{x})$ at the similarity value $\sim 50$ and $C$. ovalifolium and $C$. rivulorum have clustered (y) together with similarity value of $\sim 33$. C. dubium is clustered with C. ovalifolium and C. rivulorum cluster with similarity value at $\sim 28$. C. capparu-corindo and C. citriodorum cluster (x) is linked with other two clusters $\mathrm{y}$ and $\mathrm{z}$ with the least similarity values of 19. Figure 4b shows the score plot of Cinnamomum species based of petiole anatomy and the first and second Principal Components explain $31.76 \%$ and $24.84 \%$ of total variations respectively. In general, the PCA revealed a high distribution of characters but without correlation among the species, which indicates a morphological diversity of plants among the species.

PCA showed that the accumulative contribution rate of the three principal components were $58.38 \%$. Thus the first, second and third principal components had more than 0.637 . The PCA revealed that acicular crystals (AC), cluster of crystals (CC), trichomes (T), box-like bundles (BL) and trichomes abundance (TA) contribute to the first component (F1) that account for $31.76 \%$ total variance (Figure $4 \mathrm{~b}$ ) Shape of the petiole (SH), upper surface wings (USW) and raphides (R) are the major loading characters to the second component (F2) that explained $24.84 \%$ total variance and showed the high variation (Figure 4b). Some characters such as upper surface groove (USG) and elongated shaped crystals (ES) are the loading factors for third component. These variables, therefore, are predicted to affect the distribution patterns of petiole anatomy of all species. These data will contribute to enhance the petiole anatomy of Cinnamomum species.

\subsection{Identification key}

It was possible to build an indented taxonomic (diagnostic) key based on petiole anatomical characters observed of the Cinnamomum species for the Sri Lankan members of the genus Cinnamomum. 
1a. Non-symmetrical along the vertical axis of the petiole (in LS) ..... go to 2

b. Symmetrical along the vertical axis of the petiole (in LS) go to 3

2a. Presence of unicellular trichomes on the adaxial surface, oval shaped, vascular bundle clearly separated into three segments, stone cells were isodiametric shape, observable pits, finely porous C. dubium

2b. Absence of trichomes on the adaxial surface, reniform shape of the petiole, vascular bundle partially dissected into 3 segments, stone cells were isodiametric, observable pits, strongly porous stone cells C. litseaefolium

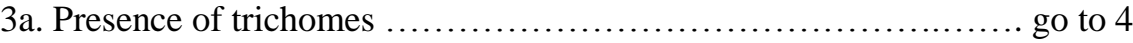

3b. Absence of trichomes ....................................... go to 5

4a. Unicellular and bicellular trichomes, round shaped, simple open arc vascular bundle, stone cells were isodiametric shape, remarkable pits, small pore and slight grove on the adaxial surface .... C. ovalifolium

4b. Unicellular and bicellular trichomes, roundish shaped, simple open arc vascular bundle stone cells were isodiametric shape, observable pits, small pore and deep grove on the adaxial surface C. rivulorum

5a. Wing extensions were absent, vascular bundle partially dissected into 3 segments, stone cells were elongated shape, remarkable pits finely porous C. appru-corindo

5b. Wing extensions were present, simple open arc vascular bundle

6a. Stone cells were elongated shape, strongly porous, pits not go to 6 observable C. citrodorum

6b. Simple open arc with slightly curved ends

a. Stone cells were elongated, remarkable pits, finely porous go to 7 C. sinharagense

7b. Stone cells were isodiametric, observable pits, small pore C. verum

\section{Conclusions}

The present study revealed the polymorphism of petiole anatomy of the genus Cinnamomum. Presence of upper surface wings, upper surface grooves, trichome characters, shape and structure of vascular bundle, stone 
cell characters (shape, structure, pits and pore size) were some of the key characters for identification of Cinnamomum species. Upper surface wings were observed only on petiole of C. capparu-corindo. Vascular bundle is clearly separated into three segments and partially dissected into 3 segments in C. dubium and C. litseaefolium respectively. Trichomes were absent on the adaxial surface of the C. capparu-corindo, C. citrodorum, $C$. sinharagense and C. verum. Moreover, these data may be helpful to fill the gap on the petiole anatomy of Laurals. The application of cluster analysis revealed that Cinnamomum species mainly grouped into three main clusters. The present findings could provide valuable anatomical information for future research in identifying the Cinnamomum species.

\section{Acknowledgements}

The first author was financially supported by the Endeavour Research Fellowship (ERF_PDR_2014_4408). Authors are grateful to Director General, Dept. of Export Agriculture, Kandy Road, Peradeniya and Director and staff of Cinnamon Research Station, Dept. of Export Agriculture, Palolpitiya, Matara, Sri Lanka. Dr. Melodina Fabillo, Dr. Hernán Retamales and other members of the Plant Structure and Systematics group (EEBS, QUT) and technical staff in the Science and Engineering Faculty (SEF) are acknowledged for assistance with logistics and training in plant anatomy techniques. Data reported in this paper were obtained at the Central Analytical Research Facility (CARF) operated by the Institute for Future Environments at QUT, with assistance from Rachel Hancock and Sanjleena Singh. Ailsa Holland and other staff at the Queensland Herbarium (BRI) are thanked for their advice and logistical support pertaining to sending specimens from Sri Lanka to Australia. We thank anonymous reviewers for comments.

\section{References}

Abeywikrama 1973. Fosberg FR. Clayton WD. (ed.) 1973. A revised handbook to the flora of Ceylon, (pp105), New Delhi: Amerind Publishing Co. Pvt Ltd.

Aguoru CU, Okoli BE. 2012. Comparative stem and petiole anatomy of West African species of Momordica L (Cucurbitaceae). African Journal of Plant Science 6(15): 403-409.

Akçin OE, Özyurt MS, Şenel G. 2011. Petiole anatomy of some Lamiaceae taxa. Pakistan Journal of Botany 43(3): 1437-1443.

Anon D. 2006. Administrative Report. Department of Export Agriculture, Peradeniya, Sri Lanka.

Ayomipo AT, Johnson AA. 2015. Petiole anatomy of the genus Basella in South Western Nigeria. Journal of Plant Science 10(1): 35-41.

Bakker ME, Gerritsen AF. van der Schaaf PJ. 1992. Leaf anatomy of Cinnamomum schaeffer (Lauraceae) with special reference to oil and mucilage cells. Blumea 37: 1-30.

Baruah A, Nath SC. 2006. Leaf anatomy and essential oil characters of Cinnamomum pauciflorum Nees - a potential spice crop from North-East India. Journal of Spices and Aromatic Crops 15(1): 52-56.

Coutinho DF, Agra MF, Basílio IJLD. Barbosa-Filho JM. 2006. Morphoanatomical study of the leaves of Ocotea duckei Vattimo (Lauraceae-Lauroideae). Brazilian Journal of Pharmacognosy 16(4): 537-544. 
Faixov Z, Faix R. 2008. Effect of dietary essential o1l extract on blood variables of broler chickbns. Folia Veterinaria 52(2): 71-72.

Gorovoy PG, Boltenkov EV, Yakovleva OV, Doudkin RV. 2011. Taxonomicv of petiole anatomy in the genus Megadenia Maxim. (Cruciferae). Doklady Biological Sciences 439(1): 129-131.

Hyland BPM. 1986. A revision of Lauraceae in Australia (excluding Cassytha). PhD thesis, James Cook University of North Queensland.

Huang BQ and Yeung EC. 2015. Chemical and physical fixation of cells and tissues: An Overview. Plant micro techniques and protocols. In Yeung ECT, Stasolla C, Sumner MJ, Huang BQ (Ed.). (pp. 23-32). Springer International Publishing Switzerland.

Ingole SN, Kaikade RS. 2015. Study of Petiolar Anatomy of Some Medicinal Plants Mentioned in the Atharvaveda. International Journal of Research Studies in Biosciences (IJRSB) 3(3): 103-106.

Jackson MT. 2005. Sassafras albidum (Nutt.) Nees. The Mitteu tree. Indiana native plant and wildflower Society 4: 4-5.

Kamel EA, Loufty MHA. 2001. The significance of cuticular features, petiole anatomy and SDS-PAGE in the taxonomy of the Lauraceae. Pakistan Journal of Biological Sciences 4(9): 1094-1100.

Khan A, Safdar M, Muzaffar M, Khan A, Khan NK. Anderson RA. 2003. Cinnamon improves glucose and lipids of people with type 2 diabetes. Diabetes Care 26: 3215-3218.

Kocsis M, Borhidi A. 2003. Petiole anatomy of some Rubiaceae genera. Acta Botanica Hungarica 45: 345-353.

Long C, Oskolski A. 2018. Wood and bark anatomy of Andriana (Heteromorpheae, Apiaceae) with phylogenetic implications. South African Journal of Botany. 115: 138-142

Mabel AF, Johnson AK, and Temitope OO. 2013. Petiole anatomy of some species of Asteraceae in southwest Nigeria. African Journal of Plant Science 7(12): 608-612.

Martínez-Cabrera D, Terrazas T, Ochoterena H. 2009. Foliar and Petiole Anatomy of Tribe Hamelieae and Other Rubiaceae. Annals of the Missouri Botanical Garden 96(1): 133-145.

Metcalfe CR, Chalk L. 1972. Anatomy of the Dicotyledons Vol 2. 4th ed. (pp. 240), Oxford University Press, London.

Matias LQ, Soares A, Scatena VL. 2007. Systematic consideration of petiole anatomy of species of Echinodorus Richard (Alismataceae) from north-eastern Brazil. Flora 202: 395402.

Michael O, Soladoye FLS. 1982. Comparative petiole anatomy as an aid tothe classification of the African genus Baphia Lodd. (Leguminosae-Papilionoideae-Sophoreae). Botanical Journal of the Linnean Society (1982), 85: 297-313.

MOE 2012. The National Red List 2012 of Sri Lanka; Conservation Status of the Fauna and Flora. Ministry of Environment, Colombo, Sri Lanka. viii + 476pp.

Nishida S, van der Werff H. 2007. Are cuticular characters useful in solving generic relationships of problematic species of Lauraceae? Taxon 56(4): 1229-1237.

Noraini T, Ruzi, AR, Ismail BS. Ummu BH. Salwa S. Azij A. 2016. Petiole vascular bundles and its taxonomic value in the Tribe Dipterocarpeae (Dipterocarpaceae). 45(2): 247-253.

Nwokwa RC, Onuoha FN, Uzoma PC, Obasi HC, Onuegbu G, Ezeh VO. 2014. Antimicrobial finishing action of Camphora for cotton and polyester fabrics. The International Asian Research Journal 2(2): 37-40.

Özdemir A, Özdemir AY, Yetisen K. 2016. Statistical comparative petiol anatomy of Salvia SP. Planta Daninha, Viçosa-MG. 34(3): 465-474.

Pugazhenthi M, Suganthi R. 2013. Screening of phytochemicals and antibacterial poteninal of Laurus nobilis. Global Journal of Molecular Biology \& Techniques 3(2):21-24.

Retamales HA, Retamales A, Serra MT, Scharaschkin T. 2015. Leaf micromorphology and anatomy of Myrceugenia rufa (Myrtaceae). An endemic coastal shrub of north-central Chile. Gayana Botany 72(1): 76-83.

Senaratna LK. 2001. A check list of the flowering plants of Sri Lanka. Published by the National Science Foundation, Sri Lanka. 
Sharma BG, Albert S, Dhaduk HK. 2012, Petiolar Anatomy as an Aid to the Identification of Mangifera indica L. Varieties. Notulae Scientia Biologicae 4(1): 44-47.

Shahri SMM, Jafari A, Mahmoodzadeh H. 2016. Comparative Anatomical Studies on Petioles of Nepeta L. Species (Lamiaceae) in NE Iran. Advanced Studies in Biology. 8(3):119 - 126.

Smerq J, Sharma M. 2011. Possible mechanism of Murraya koenigii and Cinnamomum tamala with reference to antioxidants activity. International Journal of Pharmaceutical Sciences and Drug Research 3(3): 260-264.

Sritharan R. 1984. The study of the Genus Cinnamomum. M. Phil thesis, Post Graduate Institute of Agriculture, University of Peradeniya (PGIA), Peradeniya, Sri Lanka.

Talip N, Cutler DF, Puad ASA, Ismail BS, Ruzi AR, Juhari AAA. 2017. Diagnostic and systematic significance of petiole anatomy in the identification of Hopea species (Dipterocarpaceae). South African Journal of Botany 111: 111-125.

Vun O, Mbagwu FN, Inyama CN, Ukpai KU. 2015. Systematic Characterization of Six Citrus Species Using Petiole Anatomy. Medicinal and Aromatic Plants. http://dx.doi.org/10.4 172/2167-0412.S1-005.

Wang Y, Avula B, Nanayakkara NPD, Zhao J, Khan IA. 2013. Cassia cinnamon as a source of coumarin in cinnamon-flavored food and food supplements in the United States. Journal of Agricultural and Food Chemistry 61(18): 4470-4476. 